\title{
Original article (short paper) \\ Effect of a physical activity program on sport enjoyment, physical activity participation, physical self-concept and quality of life in children with asthma
}

\author{
Pedro Ángel Latorre-Román \\ Ana Vanesa Navarro Martínez \\ Felipe García-Pinillos \\ University of Jaen, Úbeda, Spain
}

\begin{abstract}
This study aims to analyse the effects of indoor physical training program on the enjoyment and the willingness to participate in sports activities, physical self-concept and the quality of life in children with asthma. Participants were randomized in an experimental group $(\mathrm{EG})(n=58$, age $=11.55 \pm 1.01$ years old $)$ and, a control group $(\mathrm{CG})(n=47$, age $=11.51 \pm 1.42$ years old $)$. An indoor training program was executed for 12-week, with each week containing three sessions of 60 minutes. Enjoyment in physical activity questionnaire, participation in physical activities, physical self-concept questionnaire, 6 minute walking test, and paediatric asthma quality of life questionnaire were employed. After the intervention, EG showed a significant reduction in the body mass index as well as a significant improvement in physical fitness test and the score obtained in questionnaires compared to the CG. A12-week indoor training program targeted towards asthmatic children improved the sport enjoyment, physical activity participation, physical self-concept, and quality of life.
\end{abstract}

Keywords: asthma, children, physical exercise, quality of life

Resumo - "Efeito de um programa de atividade física no gozo esporte, a participação da atividade física, auto-conceito físico e qualidade de vida em crianças com asma." O objetivo estudo foi analisar o efeito de um programa de treinamento indoor no prazer e na intenção de prática de esportes, no autoconceito físico e na qualidade de vida em crianças com asma. Participantes foram divididos aleatoriamente em grupo experimental (GE) $(n=58$, idade $=11,55 \pm 1,01$ anos), e grupo de controle (GC) $(n=47$, idade $=11,51 \pm 1,42$ anos). Foi ministrado um programa de treinamento indoor de 12-semanas, com 3 sessões semanais de 60-minutos de duração. Foram utilizados os questionários autoconceito físico, 6-Minutes Walk Test (6MWT) e questionário de qualidade de vida de asma pediátrico. O programa de treinamento GE reduziu o IMC, além de melhorar as pontuações nos vários testes e questionários preenchidos, contrário do GC. O programa de treinamento indoor de 12-semanas aumentou o prazer da prática da atividade física, a participação da atividade física, o autoconceito físico e a qualidade de vida em crianças com asma.

Palavras-chave: asma, crianças, exercício, qualidade de vida

Resumen - "Efecto de un programa de actividad física en el disfrute de deportes, la participación en la actividad física, el autoconcepto físico y la calidad de vida en niños con asma." El objetivo del estudio fue analizar el efecto de un programa de entrenamiento indoor en el disfrute e intención de participar en actividades deportivas, autoconcepto físico y calidad de vida en niños con asma. Participantes fueron randomizados en grupo experimental (GE) ( $n=58$, edad= 11,55 $\pm 1,01$ años), $\mathrm{y}$ grupo control (GC) $(n=47$, edad=11,51 $\pm 1,42$ años). Se llevó a cabo un programa de entrenamiento indoor de 12-semanas, con 3 sesiones semanales de 60-minutos. El cuestionario de disfrute en actividades físicas, participación en actividades físicas, autoconcepto físico, 6-minute walking test y cuestionario de calidad de vida de asma pediátrico fueron empleados. A diferencia del GC, para el GE el programa de entrenamiento provocó una reducción en IMC, además de una mejora en las puntuaciones obtenidas en el test de condición física y la puntuación de los cuestionarios cumplimentados. Un programa de entrenamiento indoor de 12-semanas mejoró el disfrute de la actividad física, la participación en actividades físicas, el autoconcepto físico y calidad de vida en niños con asma.

Palabras claves: asma, niños, ejercicio físico, calidad de vida

\section{Introduction}

Physical activity may be useful in the management of asthma (Verlaet et al.,1976) and in improving the management of asthma symptoms (Eijkemans, Mommers, Draaisma, Thijs, \& Prins,
2012; Van der Horst, Twisk, \& Van Mechelen, 2007), pulmonary function, mental health (Avallone \& McLeish, 2013), and quality of life (Wirrell, Cheung, \& Spier, 2006). High physical fitness seems to be associated with risk reduction of developing asthma (Rasmussen, Lambrechtsen, Siersted, Hansen, \& Hansen, 2000). 
Nevertheless, children with asthma, especially those with a more severe clinical disease, tend to have a sedentary lifestyle and therefore a lower aerobic capacity than in healthy children (Kathiresan \& Paulraj, 2010). Fear of breathlessness and induced asthma attacks inhibits participation in physical activity and sport in many patients (Welsh, Kemp, \&Roberts, 2005).

Certain psychological factors such as self-identity, self-efficacy, perceived competence, enjoyment of physical activity and motivation influence the individual's attitude and therefore, their participation in the physical activity (Kohl \& Hobbs, 1998). Previous research has revealed that a positive perception of physical competence is linked to enjoyment in physical exercise (Fairclough, 2003) and that a positive association exists between self-efficacy and physical activity (Van der Horst, Twisk, \& Van Mechelen, 2007). Children who are more active, enjoy sport, have confidence in their capability to be physically active, feel competent, will perceive fewer barriers to physical activity in the future, and will be more likely to enjoy physical exercise throughout their lives (Biddle, Gorely, \& Stensel, 2004; Dishman et al., 2005). Enjoyment is often cited as an important correlate or predictor of physical activity participation and it is included in many health promotion models and behaviour motivation theories (Dacey, Baltzell, \& Zaichkowsky, 2008).

Negative past experiences with exercise may result in unpleasant perceptions of physical activity involvement, leading to a vicious cycle of sedentary habits (Pianosi \& Davis, 2004; Welsh et al., 2004). Asthmatic children who experience the benefits of exercise are more likely to be active throughout their lives. However, there is limited research focusing on attitudes toward exercise from the perspective of school-aged children with asthma (Dimitrakaki et al., 2013). More research focusing on the connection between asthmatic children to sport is needed. It is necessary to exam the correlation between insufficient physical activity and sedentary behaviours in order to develop effective interventions that may help children and adolescents with asthma reduce the time it takes to develop inactive behaviours. It is therefore important to progress in the investigation that will ultimately acquire a clearer understanding of the motivational mechanisms that underlie the positive or negative outcomes of physical education, such as enjoyment in children with asthma.

Considering the benefits of physical activity for health of children with asthma, it was hypothesized that indoor exercise training improving sport enjoyment, physical activity participation and quality of life in children with asthma. Therefore, the aim of this study is to analyse the effects of physical activity program on sport enjoyment, physical activity participation, physical self-concept, and quality of life in children with asthma.

\section{Methods}

\section{Participants}

This study included 118 students (age $=11.53 \pm 1.20$ years; age range: 10-14 years) diagnosed with asthma by the allergy specialists in hospitals in Ubeda and in Jaen (Andalusia, Spain). All children were deemed eligible by the following criteria: diagnosis of asthma severity according to the Global Initiative for Asthma (GINA, 2011), have undergone treatment for at least
6 months before the study and were in a stable phase of the disease. This stable phase means that the children's disease was not exacerbated during that time, no recent changes in drug use were made, nor did they suffer from other cardiopulmonary diseases, musculoskeletal problems or mental disabilities. All parents of students completed an informed consent form which met the ethical standards of the World Medical Association Declaration of Helsinki. The study was approved by the Bioethics Committee of the University of Jaen. Finally, 105 children were randomized into experimental group $(\mathrm{EG} ; n=58$; age $=11.55 \pm 1.01$ years; $51.7 \%$ boys and $48.3 \%$ girls) and control group (CG; $n=47$; age $=11.51 \pm 1.42$ years; $70.2 \%$ boys and $29.8 \%$ girls $)$. Figure 1 shows the flowchart of participants during the study.

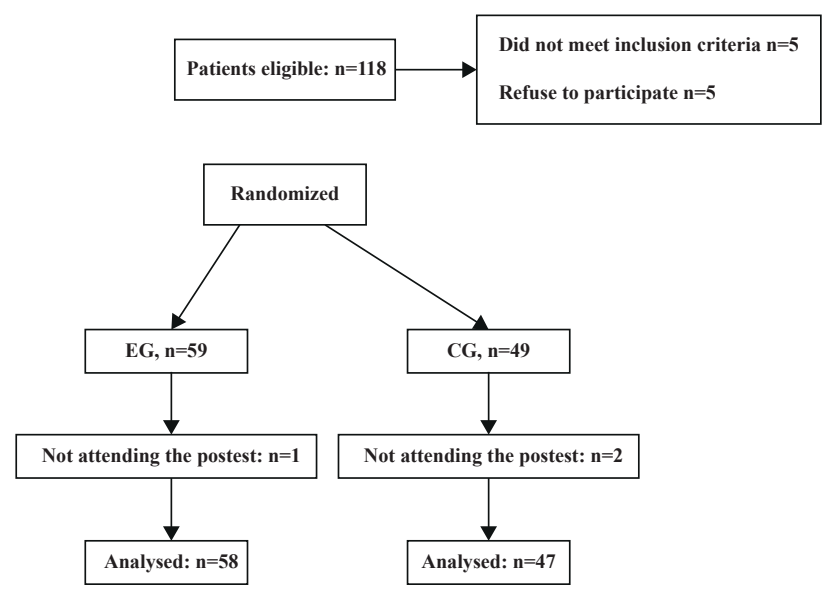

Figure 1. Flowchart progress through the study's participants.

\section{Instruments and testing}

The anthropometric parameters analysed included height $(\mathrm{m})$, measured with a stadiometer (Seca 222, Hamburg, Germany), body mass (kg), recorded with a Seca 634 (Hamburg, Germany), and the body mass index $(\mathrm{BMI})=$ body mass $(\mathrm{kg}) /$ height $\left(\mathrm{m}^{2}\right)$. Aerobic endurance was measured through a six minute walk test (6MWT) (American Thoracic Society; American College of Chest Physicians, 2003), which is a sub-maximal test useful to examine the functional capacity in individuals with moderate to severe asthma. It looks carefully at the distance that an individual can walk quickly in a rectangle of 45.57 metres during 6 minutes (Rikli \& Jones, 1999). For the assessment of perceived exertion (RPE) after the completion of 6MWT, the Borg scale (Borg, 1982) was used to established items from 0-10 (low intensity to high intensity). To test the enjoyment of the physical activity, Physical Activity Enjoyment Scale (Motl et al., 2001), Spanish version (Moreno, González-Cutre, Martínez, Nestor, \& López, 2008) was used. This scale consists of 16 items, preceded by the sentence "When I am active...," and evaluates the enjoyment from the highest level (e.g., "I enjoy," "It is very exciting," "I find it enjoyable") to the lowest (e.g. "I am bored," "I do not like it," "It frustrates me"). The answers were collected in a Likert scale whose punctuation ranks oscillate from 1 (totally disagree) to 5 (totally agree). Cronbach's alpha in this study was .907 . The physical activity was calculated with the 
Physical Activity Questionnaire for Children (PAQ-C) (Kowalski, Crocker, \& Kowalski, 1997). The PAQ-C, which is appropriate for school children (8-14 years old), registers the physical activity performed 7 days prior its administration. We used the teenager version of Martínez-Gómez et al. (2009) translated into Spanish and updated from its children's version. Cronbach's alpha in this study was .726. To analyse the quality of life of asthmatic children PAQLQ (Paediatric Asthma Quality of Life Questionnaire) was used in its Spanish version (Tauler et al., 2001). This questionnaire was developed for asthmatic children from 7 to 17 years of age to evaluate the quality of life. It is composed of 23 questions (items) distributed into three fields: symptoms, limitation in activities and emotional function. Their answers are coded in a Likert scale with options from 1 (lowest quality of life) to 7 (highest quality of life). Cronbach's alpha in this study was .958. To test the physical self-concept, CAF questionnaire was used (Goñi, Azúa, \& Liberal, 2004) it is composed of 36 items divided into four scales of physical self-concept (physical attractiveness, physical ability, fitness and strength) and two for the physical self-general and general self-concept. Cronbach's alpha in this study was .922 .

\section{Intervention}

The intervention consisted of three 60-minute sessions of physical indoor exercise training per week for 12 weeks, with meetings on Monday, Wednesday and Friday. The structure of the session consisted of a 10 minute warm-up, a 35 minute program of activities and a 10 minute cool down. The type of physical sports program was in accordance with the criteria of the American College of Sports Medicine (ACSM, 1999), which recommended that the exercise program designed for people with asthma ensure that they develop tolerance to cardio respiratory activities as these specific activities use large aerobic muscles. It is recommended that these people do indoor sports, meaning that most of the sessions were conducted in indoor sports facilities away from pollution and allergens (ACSM, 1999). The intensity of the exercises was self-administered by the participants. Cardiovascular exercises included walking at different speeds, running, aerobic dance and other continuous and rhythmic activities that involved great muscle groups, self-loading exercise, loading exercises with a companion, flexibility, relaxation and team sports. Exercise intensity was increased during the whole program, by modifying the number of reps per set, by increasing movement speed and by reducing rest time between exercises. The goal given to the tasks was control of skills rather than competition.

\section{Statistical analysis}

Data were analysed using SPSS., V.19.0 for Windows (SPSS Inc, Chicago, USA) and the significance level was set at $p<.05$. The data are shown in descriptive statistics for mean and standard deviation. Analysis of covariance (ANCOVA) with the analysis was performed on pre- and pos-test using sex as a covariate and ANCOVA with post-pre-test differences, taking the pre-test and sex as covariates. We performed Spearman correlation between the enjoyment and the rest of the variables analysed.

\section{Results}

Table 1 shows results of BMI, enjoyment of physical activity, physical activity participation and quality of life in asthmatic children. Table 2 shows the results of physical self-concept and 6MWT. After the intervention, a significant reduction of BMI ( $p$ $<.001$ ), were produced in EG, while CG remained unchanged. Likewise, a significant increase $(p<.001)$ in sport enjoyment, physical activity participation, quality of life in children with asthma, physical self-concept and walk distance in 6MWT, were produced in EG in relation to CG. This improvement in 6MWT performance was accompanied by a significant reduction in RPE postest $(p<.001)$ in EG. It should be highlighted the significant increase $(p<.001)$ in the participation of physical activities in EG's school (items 2 and 3 ) in relation to that same participation in CG.

Table 1. Anthropometric variables, enjoyment of physical activity questionnaire (PACES), physical activity questionnaire (PAQ-C), quality of life of paediatric asthma questionnaire (PAQLQ).

\begin{tabular}{|c|c|c|c|c|}
\hline & & $\begin{array}{l}\text { Pre-test } \\
M(S D)\end{array}$ & $\begin{array}{c}\text { Post-test } \\
M(S D)\end{array}$ & $\begin{array}{c}\text { Post-pre- } \\
\text { difference } M(S D)\end{array}$ \\
\hline \multirow[t]{2}{*}{ BMI $\left(\mathrm{kg} / \mathrm{m}^{2}\right)$} & $\mathrm{CG}$ & $21.39(4.78)$ & $21.84(4.57)$ & $0.44(2.61)$ \\
\hline & EG & $19.69(3.20)$ & $17.49(2.75)$ & $-2.19(2.22)$ \\
\hline p-value & & .049 & $<.001$ & $<.001$ \\
\hline \multirow[t]{2}{*}{ PACES } & $\mathrm{CG}$ & $4.07(0.68)$ & $4.11(0.69)$ & $0.04(0.72)$ \\
\hline & EG & $4.18(0.71)$ & $4.85(0.26)$ & $0.67(0.71)$ \\
\hline p-value & & NS & $<.001$ & $<.001$ \\
\hline \multirow[t]{2}{*}{ PAQ-C } & $\mathrm{CG}$ & $2.75(0.72)$ & $2.71(0.70)$ & $-0.03(0.82)$ \\
\hline & EG & $2.50(0.61)$ & $4.12(0.43)$ & $1.61(0.70)$ \\
\hline p-value & & NS & $<.001$ & $<.001$ \\
\hline \multirow[t]{2}{*}{ Items 2} & $\mathrm{CG}$ & $3.40(1.51)$ & $3.55(1.31)$ & $0.15(1.60)$ \\
\hline & EG & $3.47(1.21)$ & $4.52(0.70)$ & $1.05(1.45)$ \\
\hline$p$-value & & NS & $<.001$ & $<.001$ \\
\hline \multirow[t]{2}{*}{ Items 3: } & $\mathrm{CG}$ & $2.55(1.55)$ & $2.43(1.41)$ & $-0.12(1.81)$ \\
\hline & EG & $1.90(1.20)$ & $4.38(0.95)$ & $2.48(1.32)$ \\
\hline p-value & & .031 & $<.001$ & $<.001$ \\
\hline PAQLQ & $\mathrm{CG}$ & $3.89(1.74)$ & $3.99(1.64)$ & $0.10(1.58)$ \\
\hline $\begin{array}{l}\text { Activity } \\
\text { limitation }\end{array}$ & EG & $3.66(1.32)$ & $6.78(0.35)$ & $3.12(1.35)$ \\
\hline p-value & & NS & $<.001$ & $<.001$ \\
\hline PAQLQ & $\mathrm{CG}$ & $4.05(1.67)$ & $3.95(1.58)$ & $-0.10(1.83)$ \\
\hline Symptoms & EG & $4.11(1.41)$ & $6.71(0.43)$ & $2.60(1.52)$ \\
\hline p-value & & NS & $<.001$ & $<.001$ \\
\hline PAQLQ & $\mathrm{CG}$ & $4.94(1.62)$ & $4.49(1.63)$ & $-0.45(1.79)$ \\
\hline $\begin{array}{l}\text { Emotional } \\
\text { function }\end{array}$ & EG & $4.69(1.46)$ & $6.71(0.45)$ & $2.02(1.50)$ \\
\hline$p$-value & & NS & $<.001$ & $<.001$ \\
\hline PAQLQ & $\mathrm{CG}$ & $4.32(1.55)$ & $4.15(1.50)$ & $-0.17(1.55)$ \\
\hline Total & EG & $4.21(1.33)$ & $6.72(0.38)$ & $2.51(1.39)$ \\
\hline$p$-value & & NS & $<.001$ & $<.001$ \\
\hline
\end{tabular}

*CG (control group). EG (experimental group).M (mean). $\mathrm{SD}$ (standard deviation). NS. No significant. BMI: body mass index. PACES (enjoyment in physical activity questionnaire).PAQ-C (participation in physical activities). Items 2: In the last 7 days, during your physical education (PE) classes, how often were you very active (playing hard, running, jumping, throwing)? Items 3 : In the last 7 days, what did you do most of the time at recess? (The lowest activity response being a 1 and the highest activity response being a 5). PAQLQ (Paediatric Asthma Quality of Life Questionnaire). ANCOVA with the analysis was performed on pre- and post-test using sex as a covariate and ANCOVA with post-pre- differences, taking the pretest and sex as covariates. 
Table 2. Results obtained in physical self-concept questionnaire (CAF), six-minute walk test (6MWT) and RPE.

\begin{tabular}{|c|c|c|c|c|}
\hline & & $\begin{array}{l}\text { Pre-test } \\
M(S D)\end{array}$ & $\begin{array}{c}\text { Post-test } \\
M(S D) \\
\end{array}$ & $\begin{array}{c}\text { Post-pre-difference } \\
M(S D) \\
\end{array}$ \\
\hline \multirow[t]{2}{*}{ Ability (CAF) } & $\mathrm{CG}$ & $22.87(5.53)$ & $21.02(5.57)$ & $-1.85(5.15)$ \\
\hline & EG & $22.47(4.12)$ & $28.83(1.81)$ & $6.36(3.78)$ \\
\hline p-value & & NS & $<.001$ & $<.001$ \\
\hline \multirow[t]{2}{*}{ Fitness (CAF) } & $\mathrm{CG}$ & $21.13(6.90)$ & $21.62(5.76)$ & $0.49(5.53)$ \\
\hline & EG & $20.69(4.26)$ & $28.59(1.82)$ & $7.90(4.13)$ \\
\hline p-value & & NS & $<.001$ & $<.001$ \\
\hline \multirow[t]{2}{*}{ Attractive (CAF) } & $\mathrm{CG}$ & $20.26(3.97)$ & $23.09(4.18)$ & $2.83(3.29)$ \\
\hline & EG & $20.17(3.92)$ & $28.10(2.26)$ & $7.93(4.24)$ \\
\hline p-value & & NS & $<.001$ & $<.001$ \\
\hline \multirow{2}{*}{ Strength (CAF) } & $\mathrm{CG}$ & $22.13(5.85)$ & $23.89(5.18)$ & $1.77(5.47)$ \\
\hline & EG & $21.22(5.00)$ & $29.22(1.47)$ & $8.00(4.91)$ \\
\hline$p$-value & & NS & $<.001$ & $<.001$ \\
\hline \multirow{2}{*}{$\begin{array}{l}\text { General physical self- } \\
\text { concept (CAF) }\end{array}$} & $\mathrm{CG}$ & $25.19(4.49)$ & $19.60(4.54)$ & $-5.59(4.85)$ \\
\hline & EG & $24.26(4.68)$ & $24.16(1.56)$ & $-0.10(4.59)$ \\
\hline$p$-value & & NS & $<.001$ & $<.001$ \\
\hline \multirow{2}{*}{$\begin{array}{l}\text { General self-concept } \\
\text { (CAF) }\end{array}$} & CG & $24.89(3.52)$ & $23.43(5.76)$ & $-1.47(5.52)$ \\
\hline & EG & $22.19(4.63)$ & $29.14(1.31)$ & $6.95(4.80)$ \\
\hline$p$-value & & .001 & $<.001$ & $<.001$ \\
\hline \multirow[t]{2}{*}{$6 \mathrm{MWT}(\mathrm{m})$} & CG & $666.79(71.22)$ & $654.31(99.42)$ & $-12.48(130.43)$ \\
\hline & EG & $739.60(71.60)$ & $916.09(79.42)$ & $176.49(96.92)$ \\
\hline p-value & & $<.001$ & $<.001$ & $<.001$ \\
\hline \multirow[t]{2}{*}{ RPE (0-10) } & CG & $4.37(2.89)$ & $3.89(3.05)$ & $-0.47(1.99)$ \\
\hline & EG & $5.15(2.11)$ & $0.73(1.06)$ & $-4.42(1.97)$ \\
\hline p-value & & NS & $<.001$ & $<.001$ \\
\hline
\end{tabular}

*CG (control group). EG (experimental group). M (mean).SD (standard deviation). NS. No significant. CAF (physical self-concept questionnaire). $6 \mathrm{MWT}$ (6 minute walk test). RPE (Rating of Perceived Effort). ANCOVA with the analysis was performed on pre- and post-test using sex as a covariate and ANCOVA with post-pre- differences, taking the pre-test and sex as covariates.

Table 3 shows Spearman correlation between the physical activity enjoyment and the increase of variables analysed in this study. The increase of the enjoyment positively correlates with $\triangle$ PAQ-C , $\Delta$ items $2, \Delta$ items $3, \Delta$ limitation of activities , $\Delta$ symptoms,$\Delta$ emotional function , $\triangle$ PAQLQ total,$\Delta$ walking metres in $6 \mathrm{MWT}$ and $\triangle \mathrm{CAF}$.

Table 3. Spearman correlation between physical activity enjoyment and the increase (post-pre differences) of variables analysed in this study.

\begin{tabular}{|c|c|c|}
\hline & Rho of Spearman & $p$-value \\
\hline$\triangle \mathrm{PAQ}-\mathrm{C}$ & .383 & $<.001$ \\
\hline$\Delta$ Items 2 & .258 & .008 \\
\hline$\Delta$ Items 3 & .246 & .011 \\
\hline$\Delta$ activity limitation & .361 & $<.001$ \\
\hline$\Delta$ symptoms & .313 & .001 \\
\hline$\Delta$ emotional function & .365 & $<.001$ \\
\hline$\triangle \mathrm{PAQLQ}$ total & .365 & $<.001$ \\
\hline$\Delta 6 \mathrm{MWT}$ & .262 & .007 \\
\hline$\Delta$ Ability & .357 & $<.001$ \\
\hline$\Delta$ Fitness & .190 & NS \\
\hline$\Delta$ Attractive & .153 & NS \\
\hline$\Delta$ Strength & .228 & .019 \\
\hline$\Delta$ General physicalself-concept & .342 & $<.001$ \\
\hline$\Delta$ General self-concept & .264 & .007 \\
\hline
\end{tabular}

*PAQ-C (participation in physical activities questionnaire). Items 2: In the last 7 days, during your physical education (PE) classes, how often were you very active (playing hard, running, jumping, throwing)? Items 3: In the last 7 days, what did you do most of the time at recess? PAQLQ (paediatric quality of life questionnaire). $6 \mathrm{MWT}$ (6 minute walk test). NS. No significant. 


\section{Discussion}

The average attendance at the physical activity program was $95.6 \%$, indicating a high degree of involvement by asthmatic children. The enjoyment of physical activity is an important motivation factor for children in relation to their participation in physical activities (Barr-Anderson et al., 2007; Yli-Piipari, Watt, Jaakkola, Liukkonen, \& Nurmi, 2009). The level of satisfaction in the activity realised was measured through the enjoyment of physical activity questionnaire (PACES) and significant differences between both groups were found, meaning an increase in the enjoyment for physical activity in EG in relation to CG. PACES not only value the enjoyment taken in physical or sport activity, but it is also sensitive to the enjoyment grade for other ludic activities. It can be argued that it is not only a valid measure for the adhesion to activity programs, but also for adhesion to leisure or social activities as well. Involvement in social activities is also a factor in enjoyment and satisfaction that can act as an element of social integration.

Regarding the daily physical activity of asthmatic children, several studies confirm that is lower in relation to their healthy peers (Cheng et al., 2010; Manki, Watanabe, Tabenaka, \& Ohya, 2011), especially in children with obesity (Sousa, Cabral, Martins, \& Carvalho, 2014). The PAQ-C results mark significant differences between the EG and the CG at the end of the intervention, getting an increase with higher values than those obtained by Martínez-Gómez et al., (2009) in teenagers, which emphasizes a greater involvement in physical activity in the EG. Haines and Kim (2013) also found an increase in physical activity in asthmatic children after an educative intervention of asthma and physical education. In this respect, the physical activity level is an enjoyment indicator in physical education class (Barr-Anderson et al., 2008).

Aerobic training programs are associated with an improvement in the quality of life for people with asthma (Andrade, Britto, Lucena-Silva, Gomes, \& Figueroa, 2014; Basaran et al. 2006; Silva et al. 2013). The type of indoor sports physical training performed in this study has proved beneficial to the quality of life of asthmatic children. The quality of life according to the values of restriction in activities, emotional functions, symptoms and PAQLQ total scale result consistent with other previous research (Basaran et al., 2006; Velástegui et al., 2010; Yüksel et al., 2009). The aforementioned variables increased significantly in EG whilst CG remained unchanged.

Significant improvements were found in physical self-concept in EG and significant correlations between $\triangle$ PACES with $\triangle \mathrm{CAF}$. Also, previous research has shown that perceived physical ability is associated with enjoyment in physical activity (Fairclough, 2003).

The 6MWT is a reliable and valid tool to assess functional exercise tolerance of children and it is a valid tool in assessing asthma control (Lammers, Hislop, Flynn, \&, Haworth, 2008; Li et al., 2007; Yüksel et al., 2009). Aerobic endurance improved after the intervention in EG as in other studies (Andrade et al. 2013; Basaran et al., 2006; Fernández, Roldán, \& Lopera, 2009; Van Veldhoven et al., 2001). The results obtained in the EG after training are superior to previous studies (Basaran et al., 2006; Basso et al., 2010; Geiger et al., 2007) and normative references (Lammers et al., 2008; Li et al., 2007). The increase in the 6MWT distance of EG was greater than the highest values estimated for respiratory rehabilitation of individuals with chronic obstructive pulmonary disease (Lacasse, Wong, Guyatt, King, Cook, \& Goldstein, 1996), which was $55.7 \mathrm{~m}$.

It is also highlighted in this study a positive relation between the increase of physical activity, enjoyment and the increase in the actual practise of physical activity. Additionally, a significant correlation between enjoyment of physical activity and participation in school-based physical activities was found. Sallis, Prochaska, Taylor, Hill and Geraci (1999) found that enjoyment of physical education predicted participation in physical activity in children. Moreover, an important finding of this study is the positive association between the enjoyment of physical activity and the quality of life of asthmatic children.

Finally, after the intervention, the EG improved in 6MWT, which shows that improvements in fitness were associated with positive changes in exercise enjoyment, similar result was shown in previous studies (Dunton, Schneider, \& Cooper, 2007; Fairclough, 2003).

In this study, the motivational climate created during physical activities was focused on the tasks and cooperation among participants, which could have influenced the enjoyment of physical activity. Regarding to this, Yli-Piipari et al. (2009) indicated that students with high motivation reported moderate levels of engagement in physical activity, high enjoyment in physical exercise, and low levels of state anxiety. Other authors (Grastén, Jaakkola, Liukkonen, Watt, \& Yli-Piipari, 2012) emphasize that tasks involving a motivational climate predict enjoyment in physical education via perceived physical competence and intrinsic motivation in both girls and boys.

\section{Conclusions}

According to the findings obtained, an indoor physical activity program, consisting of 3 sessions of 60 minutes per week for 12 weeks, increased the enjoyment in physical activity and the quality of life in children with asthma. Additionally, this change in quality of life was also associated with an improvement in physical activity participation and physical performance in asthmatic children. Physical activity promotion programs in children with asthma should contribute to the enjoyment of exercise, which might increase the physical exercise adherence.

\section{References}

American College of Sport Medicine (1999). Manual ACSM para la evaluación y prescripción del ejercicio. Barcelona: Paidotribo.

American Thoracic Society, \& American College of Chest Physicians. ATS/ACCP Statement on cardiopulmonary exercise testing (2003). American Journal of Respiratory and CriticalCare Medicine, 167, 211-277.

Andrade, L.B., Britto, M.C., Lucena-Silva, N., Gomes, R.G., \& Figueroa, J.N. (2014). The efficacy of aerobic training in improving 
the inflammatory component of asthmatic children. Randomized trial. Respiratory medicine, 108, 1438-1445.

Avallone, K., \& McLeish, C. (2013). Asthma and aerobic exercise: a review of the empirical literature. Journal of Asthma, 50, 109-116.

Barr-Anderson, D., Neumark-Sztainer, D., Schmitz, K., Dianne, S., Terry, L., Charlotte, P., ...Russell, R. (2008). But I like PE: Factors associated with enjoyment of physical education class in middle school girls. Research Quarterly for Exercise and Sport, 79, 18-27.

Barr-Anderson, D.J., Young, D.R., Sallis, J.F., Neumark-Sztainer, D.R., Gittelsohn, J., Webber, L., ...Jobe, J. (2007). Structured physical activity and psychosocial correlates in middle-school girls. Preventive Medecine, 44, 404-409.

Basaran, S., Guler, F., Ergen, N., Seydaoglu, T., Bingol-Karakoç, T., \& Ufuk, A.D. (2006). Effects of physical exercise on quality of life, exercise capacity and pulmonary function in children with asthma. Journal of Rehabilitation Medicine, 38, 130-135.

Basso, R., Jamami, M., Pessoa, B., Labadessa, I., Regueiro, E., \& Di Lorenzo, V. (2010). Assessment of exercise capacity among asthmatic and healthy adolescents. Brazilian Journal of Physical Therapy, 14, 252-258.

Biddle, S.J., Gorely, T., \&Stensel, D.J. (2004). Health-enhancing physical activity and sedentary behaviour in children and adolescents. Journal of Sports Science and Medicine, 22, 679-701.

Borg, G. (1982). Psychophysical bases of perceived exertion. Medicine \& Science in Sports \& Exercise, 14, 377-381.

Cheng, B.L., Huang, Y., Shu C., Lou, X.L., Fu, Z., \& Zhao, J. (2010). A cross-sectional survey of participation of asthmatic children in physical activity. World Journal of Pediatrics, 6, 238-243.

Dacey, M., Baltzell, A., \& Zaichkowsky, L. (2008). Older adults 'intrinsic and extrinsic motivation toward physical activity. American Journal of Health Behavior, 32, 570-582.

Dimitrakaki, V., Porpodis, K., Bebetsos, E., Zarogoulidis, P., Papaiwannou, A., Tsiouda, T., ...Zarogoulidis, K. (2013). Attitudes of asthmatic and no asthmatic children to physical exercise. Patient Preference and Adherence, 7, 81-88.

Dishman, R.K., Motl, R.W., Sallis, J.F., Dunn, A.L., Birnbaum, A.S., Welk, GJ., ...Jobe, J.B. (2005). Self-management strategies mediate the association of self-efficacy with physical activity among sixth and eighth grade adolescent girls. American Journal of Preventive Medicine, 29, 10-18.

Dunton, G.F., Schneider, M., \& Cooper, D.M. (2007). An investigation of psychosocial factors related to changes in physical activity and fitness among female adolescents. Health Psychology, 22, 929-944.

Eijkemans, M., Mommers, M., Draaisma, J.M., Thijs, C., \& Prins, M.H. (2012). Physical activity and asthma: a systematic review and meta-analysis. PLoS One, 7, 1-5.

Fairclough, S. (2003). Physical activity, perceived competence and enjoyment during secondary school physical education. European Journal of Physical Education, 8, 5-18.

Fernández, J., Roldán, E., \& Lopera, M. (2009). Effects of the physical training in a warm-water pool on the aerobic power of a group of asthmatic children.Revista internacional de ciencias del deporte, 16, 90-105.

Geiger, R., Strasak, A., Treml, B., Gasser, K., Kleinsasser, A., Fischer, V.,...Stein, J. (2007). Six-Minute Walk Test in Children and Adolescents. Journal of Pediatrics, 150, 395-99.
Global Strategy for Asthma Management, Prevention. Global Initiative for Asthma (GINA) guidelines 2011. www.ginasthma.org/ (accessed 11 April 2012).

Goñi, A., Azúa S., \& Liberal, I. (2004). Propiedades psicométricas de un nuevo cuestionario para la medida del autoconcepto físico. Revista de Psicología del Deporte, 13, 195-213.

Grastén, A., Jaakkola, T., Liukkonen, J., Watt, A., \& Yli-Piipari, S. (2012). Prediction of enjoyment in school physical education. Journal of Sports Science and Medicine, 11, 260-269.

Haines, M.S., \& Kim, H. (2013). A Study of the Effects of Physical Activity on Asthmatic Symptoms and Obesity Risk in Elementary School-Aged Children. American Journal of Health Education, 44, 156-161.

Kathiresan, G., \& Paulraj, A. (2010). Effect of aerobic training on airflow obstruction, VO2 max, EIB in stable asthmatic children. Health, 2, 458-64.

Kohl, H.W., \& Hobbs, K.E. (1998). Development of physical activity behaviors among children and adolescents. Pediatrics, 101, 549-554.

Kowalski, C.K., Crocker, P.R., \& Kowalski, N.P. (1997). Convergent validity of the physical activity questionnaire for adolescents. Pediatric Exercise Science, 9, 342-352.

Lacasse, Y., Wong, E., Guyatt, G., King, D., Cook, D.J., \& Goldstein, R.S. (1996). Meta-analysis of respiratory rehabilitation in chronic obstructive pulmonary disease. Lancet, 348, 1115-1119.

Lammers, A.E., Hislop, A.A., Flynn, Y., \& Haworth, S.G. (2008). The 6-minute walk test: normal values for children of 4-11 years of age. Archives of Disease in Childhood, 93, 464-468.

Li, A.M., Yin, J., Au, J., Asi, H.K., Tsang, T., Wong, E., ...Ng, P.C. (2007). Standard reference for the 6-minute walk test in healthy children aged 7 to 16 years. American Journal of Respiratory and Critical Care Medicine, 176, 174-80.

Manki, S., Watanabe, H., Tabenaka, K., \& Ohya, Y. (2011). Physical activity in asthmatic children: use of an accelerometer. Arerugi, 60, 199-206.

Martínez-Gómez, D., Martínez-de-Haro, V., Pozo, T., Welk, G.J., Villagra, A., Calle, M.E., ...Veiga, O. (2009). Fiabilidad y validez del cuestionario de actividad física PAQ-A en adolescentes españoles (Reliability and validity of Spanish adolescents PAQ-A physical activity questionnaire). Revista Española de Salud Pública, 83, 427-439.

Moreno, J.A., González-Cutre, D., Martínez, C., Nestor, A., \& López, M. (2008). Propiedades psicométricas de la Physical Activity Enjoyment Scale (PACES) en el contexto español (Psychometric properties of the Physical Activity Enjoyment Scale (peace) in the Spanish context). Estudios de Psicología, 29, 173-180.

Motl, R.W., Dishman, R.K., Saunders, R., Dowda, M., Felton, T., \& Pate, RR. (2001). Measuring enjoyment of physical activity in adolescent girls. American Journal of Preventive Medicine, 21, 110-117.

Pianosi, PT., \& Davis, HS. (2004). Determinants of physical fitness in children with asthma. Pediatrics, 113, 225-229.

Rasmussen, F., Lambrechtsen, J., Siersted, H.C., Hansen, H.S., \& Hansen, N.C. (2000). Low physical fitness in childhood associated with the development of asthma in young adulthood: the Odense schoolchild study. European Respiratory Journal, 16, 866-870. 
Rikli RE, J.J (1999) Development and validation of a functional fitness test for community residing older adults. Journal of Aging and Physical Activity, 7, 129-161.

Sallis, J.F., Prochaska, J., Taylor, W., Hill, J., \& Geraci, J. (1999). Correlates of physical activity in a national sample of girls and boys in grades 4 through 12. HealthPsychology, 18, 410-415.

Silva, D., Couto, M., Moreira, P., Padrão, P., Santos, P., Delgado, L., \& Moreira, A. (2013). Physical training improves quality of life both in asthmatic children and their caregivers. Annals of Allergy, Asthma \& Immunology, 111, 427-428.

Sousa, A.W., Cabral, A.L.B., Martins, M.A., \& Carvalho, C.R. (2014). Daily physical activity in asthmatic children with distinct severities. Journal of Asthma, 51, 493-497.

Tauler, E., Vilagut, G., Grau, G., González, A., Sánchez, E., Figueras, G., ...Alonso, J. (2001). The Spanish version of the paediatric asthma quality of life questionnaire (PAQLQ): metric characteristics and equivalence with the original version. Quality of Life Research, 10, 81-91.

Van der Horst, M.J., Twisk, J.W., \& van Mechelen, W. (2007). A brief review on correlates of physical activity and sedentariness in youth". Medicine \& Science in Sports \& Exercise, 39, 1241-1250.

Van Veldhoven, N., Vermeer, A., Bogaard J., Hessels, M.G., Wijnroks, L., Colland, V.T., \& van Essen-Zandvliet, E.E. (2001). Children with asthma and physical exercise: effects on an exercise programme. Clinical Rehabilitation, 15, 360-370.

Velástegui, C., Pérez, P., Zárate, V., Arenas, D., Salinas, P., Moreno, G., \& Prado, F. (2010). Impacto del asma en escolares de dos centros de salud primaria. Revista Médica de Chile, 138(2), 205-212.

Verlaet, A., Moreira, A., Sá-Sousa, A., Barros, R., Santos, R., Moreira, P., \& Fonseca, J. (1976). Physical activity in adults with controlled and uncontrolled asthma as compared to healthy adults: a cross-sectional study. Clinical and Translational Allergy, 15, 1-9.

Welsh, L., Kemp, J., \& Roberts, R. (2005). Effects of Physical Conditioning on Children and Adolescents with Asthma. Sports Medicine, 35, 127-141.

Welsh, L., Roberts, R.G., \& Kemp, J.G. (2004). Fitness and physical activity in children with asthma. Sports Medicine, 34, 861-870.

Wirrell, E., Cheung, C., \& Spier, S. (2006). How do teens view the physical and social impact of asthma compared to other chronic diseases? Journal of Asthma, 43, 155-160.

Yli-Piipari, S., Watt, A., Jaakkola, T., Liukkonen, J., \& Nurmi, J.E. (2009). Relationships between physical education students' motivational profiles, enjoyment, state anxiety, and self-reported physical activity. Journal of Sports Science and Medicine, 8, 327-336.

Yüksel, H., Söğüt, A., Yilmaz, Ö.,Gunay, O., Tikiz, C., Dundar, P., \& Onur, E. (2009). Effects of physical exercise on quality of life, pulmonary function and symptom score in children with asthma. Allergy, Asthma \& Immunology, 7, 58-65.

\section{Authors' note}

Pedro Ángel Latorre Román, PhD (platorre@ujaen.es), Felipe García Pinillos, PhD student (fellow research) (fegarpi@gmail.com), and Ana Vanessa Navarro Martínez, PhD, researcher (anavnavmart@ ujaen.es ) are affiliated with the University of Jaen, Department of Health Sciences, Campus de Las Lagunillas, Jaen, Spain.

\section{Acknowledgments}

The children of the province of Jaen

\section{Corresponding author}

Pedro Ángel Latorre Román

Avenida Chiclana de La Frontera 53, Úbeda, Jaén (España). 23400

Email:platorre@ujaen.es

Manuscript received on October 7, 2014

Manuscript accepted on September 16, 2015

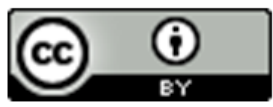

Motriz. The Journal of Physical Education. UNESP. Rio Claro, SP, Brazil - eISSN: 1980-6574 - under a license Creative Commons - Version 3.0 